\title{
Possibility of biologizing technology for protecting apple and plum trees based on the use of inorganic copper compounds
}

\author{
Galina Yakuba*, Irina Mishchenko, and Yuri Yakuba \\ Federal State Budget Scientific Institution «North Caucasian Federal Scientific Center of Horticulture, \\ Viticulture, Wine-making», 39 str. 40 Let Pobedy, Krasnodar, 350901, Russia
}

\begin{abstract}
The effectiveness of inorganic copper compounds on apple and plum trees under extreme weather conditions in 2018-2020 has been evaluated. Fungicides Koside 2000, VDG and Champ DP, VDG controlled apple scab by $98-99.6 \%$, preparations Cuproxat, KS and Terpen C, KS blocked plum clotterosporiasis by $85.1-100 \%$. The use of these fungicides did not have a negative effect on the biochemical composition of the fruit. Significant differences between the variants were found in the content of potassium and calcium cations, on the drain, in addition, in the content of sodium and magnesium cations. The possibility of biologization of protection technologies has been established: the use of the fungicide Champ DP, VDG on the apple tree, the replacement of Abiga-Peak, VS on the drain with preparations with lower consumption rates - Kuproksat, KS and Terpen $\mathrm{C}, \mathrm{KS}$. This ensures a reduction in the pesticide load on the environment, a decrease in the risk of resistance and the damaging effect of fungicides on trees weakened by stress.
\end{abstract}

\section{Introduction}

The apple and plum trees occupy a leading place in the fruit plantations of the Krasnodar region. The main diseases of these crops are apple scab Venturia inaequalis (Cke.) Wint. and clotterosporia of the plum Stigmina carpophila (Lév.) M.B. Ellis) - cause great harm to horticulture, significantly reducing the yield and deteriorating its quality. Trees weaken and become susceptible to the effects of various adverse conditions [1]. The most effective method for controlling apple scab and plum clotterosporiosis is the use of fungicides. In fruit crops, inorganic copper compounds are widely used drugs. This chemical group of compounds in agriculture, including organic farming, is quite in demand due to the high efficiency of phytopathogen control, relative environmental safety, and low risk of pathogen resistance to it [2]. Copper-catalyzed reactions have attracted increasing attention in the field of organic synthesis over the past two decades, because copper is economical and serves as an effective catalyst [3]. Research in many countries is looking for new approaches to reduce the amount of copper used. However, the results of these studies show that at present it is

\footnotetext{
* Corresponding author: galyayaku@gmail.com
} 
impossible to completely abandon copper-containing drugs [4]. Another area of research is the use of new formulations while maintaining high efficiency, since otherwise the quality and quantity of the crop may be under threat $[5,6]$. Of the group of inorganic copper compounds, copper oxychloride, copper sulfate and copper hydroxide are the most widely used practically all over the world [7-12]. On an apple tree in Russia, the effectiveness of preparations based on copper hydroxide against scab has not been sufficiently studied. Only two preparations of inorganic copper compounds are registered at the outlet for use in the Russian Federation, despite the fact that their presence in protection programs allows for the necessary rotation of the active substances of fungicides. In this regard, research on the search for effective fungicides with lower consumption rates is relevant, which makes it possible to reduce the damaging effect of chemicals on trees weakened by environmental stress. The aim of the research was to biologize technologies for protecting apple trees from scab and plums from clasterosporium disease in plantations of the Krasnodar region to ensure maximum efficiency in unstable environmental conditions. In accordance with the goal, the objectives of the study were: to assess the biological effectiveness of new and promising for the use of fungicides inorganic copper compounds against apple scab and plum clotterosporium disease; determination of the effect of the use of copper-containing preparations on the biochemical composition of apple fruits.

\section{Materials and methods}

The research was carried out in 2018-2020 in the Krasnodar region. The objects of research were fungicides of inorganic copper compounds: on an apple-tree based on copper hydroxide - Champ DP, VDG (576 g/l) and Koside 2000, VDG (350 g/kg), standard; on the drain, a new innovative mix-fungicide Terpen C, KS (400 g/l copper hydroxide); Cuproxat, KS (345 $\mathrm{g} / \mathrm{l}$ of copper sulfate tribasic) and Abiga-Peak, VS (400 g/l of copper oxychloride), standard. The work used the methods of laboratory analyzes, setting up field experiments according to generally accepted and adapted techniques [13]. Field experiments were carried out: on an apple tree - on a stationary site of ZAO OPH "Tsentralnoye", Champion variety, 2010 planting, stock M 9, planting pattern $4.5 \times 1.2 \mathrm{~m}$, tree height $2.0-2.5 \mathrm{~m}$; on the drain - in the growing station NCFSCHVW, variety Kabardinskaya early, 2001 planting, planting scheme $3 \times 2 \mathrm{~m}$, tree height 2.5-3.0 m. In both experiments, the flow rate of the working fluid - at the rate of $1000 \mathrm{l} / \mathrm{ha}$, repeatability - three times. On an apple tree, the preparations were used at the stage of culture development " $60 \%$ of the variety-typical fruit size achieved" and "70\% of the variety-typical fruit size achieved", Champ DP, VDG with a consumption rate of 2.5 $\mathrm{kg} / \mathrm{ha}$, Koside 2000, VDG with a consumption rate of $3.0 \mathrm{~kg} /$ ha. The control was treated with water. On the plum, the first two treatments were carried out at the stage of development of the culture "green cone" and "white bud", the third and fourth treatments at the stage of "ovary increases" and "second abscission of fruits (abscission of reddish fruits)" with a 10day interval. The fungicide consumption rates were: Kuproksat, KS 5.0 1/ha, Terpen C, KS $2.5 \mathrm{l} / \mathrm{ha}$, Abiga-Peak, VS $9.6 \mathrm{l} / \mathrm{ha}$ before flowering and $4.8 \mathrm{l} / \mathrm{ha}$ after flowering. The control was also treated with water. During the harvesting period, samples of apple and plum fruits were taken to determine their biochemical composition (the content of carbohydrates, minerals and acids). Analytical work was carried out at the CCU SKFNTSSVV using conventional methods (titration, refractometry, capillary electrophoresis) [14]. Statistical data processing was carried out using an Excel spreadsheet processor. 


\section{Results and discussion}

In 2018, the development of scab had the character of depression; in the control variant, $25 \%$ of leaves and about $11 \%$ of fruits were affected the maximum. At an average temperature of 2.5-3.5 ${ }^{\circ} \mathrm{C}$ above the norm and precipitation in the amount of $649 \%$ of the norm, the tested drugs provided highly effective control of the disease for 7-14 days, the number of affected leaves did not exceed $1.1 \%$, the fruits were not affected by scab were (Table 1). In 2019, with depression in the control, the number of affected leaves was $16.5 \%$ at a maximum, the number of affected fruits was $6.7 \%$. At an average temperature $2.4{ }^{\circ} \mathrm{C}$ below the norm and an amount of precipitation of $395 \%$ of the norm, the duration of the period of highly effective protection against scab of copper-containing fungicides was 8-12 days, the spread of the disease on the leaves varied from 0.1 to $0.6 \%$, the disease did not occur on fruits was discovered. In 2020, with moderate development in the control on leaves, the spread of the disease was $38.5 \%$, the intensity of development was $22.0 \%$, and on fruits, 12.5 and $5.0 \%$, respectively. In case of precipitation, also $395 \%$ of the norm, a high level of protection by the tested preparations against scab on the leaves and complete protection of fruits were ensured. Three-year studies have shown that on a highly susceptible cultivar to scab, the suppression of conidial infection was provided by copper-containing fungicides for 8-14 days at a high level: $98-99.6 \%$. The new fungicide Champ DP, VDG was not inferior to the standard version in protection against disease. The results indicate a stable and highly effective action in extreme weather conditions of modern fungicides of the group of inorganic copper compounds in the control of scab.

Table 1. Biological efficiency of using inorganic copper compounds against scab on leaves in the apple tree protection system, \%, 2018-2020.

\begin{tabular}{|c|c|c|c|}
\hline Experience variant & 2018 & 2019 & 2020 \\
\hline Champ DP, WDG & $96.8-98.8$ & $96.8-99.6$ & $98.3-99.5$ \\
\hline $\begin{array}{c}\text { Kocide 2000, WDG, } \\
\text { standard }\end{array}$ & $97.2-98.7$ & $97.0-99.4$ & $98.0-99.6$ \\
\hline Control, R, \% & $9.8-25.2$ & $5.2-7.1$ & $11.7-16.6$ \\
\hline
\end{tabular}

Legend: R - intensity of disease development, $\%$.

Note: the table shows the minimum-maximum values of the indicators during the testing period.

On the plum, during the years of research, moderate development of clasterosporium disease was noted in a variety highly susceptible to disease. When applied to the "green cone" and "white bud" of Cuproxat, KS and Terpen C, KS against the background of precipitation in the amount of $253 \%$ of the norm (2018) or, on the contrary, their small amount (45\% of the norm in 2019). and $31 \%$ in 2020), high temperature (above the norm by $1.4^{\circ} \mathrm{C}$ in 2018 and 2019 , by $2.0-9.1{ }^{\circ} \mathrm{C}$ in 2020 ), the infection was completely blocked, in the standard the effectiveness was somewhat lower (Table 2). The third and fourth plum treatments at the stage of "ovary increases" and "second fruit fall" under conditions of increased air temperature (higher than the norm by $4.3^{\circ} \mathrm{C}$ in 2018 , by $1.5-2.8^{\circ} \mathrm{C}$ in 2019 , by $1.0^{\circ} \mathrm{C}$ in 2020 ) and with rainfall in the amount of $134 \%$ of the norm (2018) or their absence (2019 and 2020), the biological effectiveness of fungicides Kuproksat, KS and Terpen C, KS was 85.1$97.0 \%$, Abiga-Peak, VS - 86.5-94.7\%. Thus, during a period of increased temperature conditions, the biological effectiveness of copper preparations against plum clotterosporia could decrease. The best efficiency was shown by the mix-fungicide Terpen $\mathrm{C}, \mathrm{KS}$. Its high efficiency is due to the fact that it contains terpenic acids in its formulation, which have high adhesive properties, and has a high level of biocidal activity against a number of types of pathogens, exhibiting a selective effect, and is also an immunomodulator [15]. 
Table 2. Biological efficiency of application of inorganic copper compounds in the protection system of plums against leaf clotterosporia,\%, 2018-2020.

\begin{tabular}{|c|c|c|c|}
\hline Experience variant & 2018 & 2019 & 2020 \\
\hline Cuproxat, SC & $100-89.4$ & $100-95.4$ & $100-97.0$ \\
\hline Terpen C, SC & $100-85.1$ & $100-90.4$ & $100-95.3$ \\
\hline Abiga-Peak, BC, standard & $98.5-86.8$ & $98.9-94.7$ & $99.0-86.5$ \\
\hline Control, R, \% & $0.5-27.0$ & $0.05-10.2$ & $0.6-16.4$ \\
\hline
\end{tabular}

It was found that in abnormal weather and climatic conditions, the use of preparations of inorganic copper compounds in apple and plum protection systems does not have a negative effect on the biochemical composition of fruits, in comparison with control samples (Tables $3,4)$. Significant differences between the variants were found in the content of potassium and calcium cations, on the drain, in addition, in the content of sodium and magnesium cations.

Table 3. Biochemical composition of apple fruits during harvest, 2018-2020

\begin{tabular}{|c|c|c|c|c|c|c|c|c|}
\hline Variant & $\begin{array}{l}\text { Dry } \\
\text { matte } \\
\mathrm{r}, \%\end{array}$ & $\begin{array}{l}\text { Apple } \\
\text { acid, } \\
\mathrm{g} / \mathrm{kg}\end{array}$ & $\begin{array}{l}\text { Ascorbi } \\
\mathrm{c} \text { acid, } \\
\mathrm{mg} / \mathrm{kg}\end{array}$ & $\begin{array}{l}\text { Succini } \\
\mathrm{c} \text { acid, } \\
\Gamma / \mathrm{\kappa} \Gamma\end{array}$ & $\begin{array}{l}\mathrm{K}, \\
\mathrm{mg} / \mathrm{k} \\
\mathrm{g}\end{array}$ & $\begin{array}{l}\mathrm{Na}, \\
\mathrm{mg} / \mathrm{k} \\
\mathrm{g}\end{array}$ & $\begin{array}{l}\mathrm{Mg}, \\
\mathrm{mg} / \mathrm{k} \\
\mathrm{g}\end{array}$ & $\begin{array}{l}\mathrm{Ca}, \\
\mathrm{mg} / \mathrm{k} \\
\mathrm{g}\end{array}$ \\
\hline \multicolumn{9}{|c|}{2018} \\
\hline $\begin{array}{l}\text { Champ DP, } \\
\text { WDG }\end{array}$ & 14.5 & 13.2 & 18.2 & 0.07 & 1425 & 16.0 & 9.6 & 49.0 \\
\hline $\begin{array}{l}\text { Kocide } 2000 \text {, } \\
\text { WDG, standard }\end{array}$ & 15.8 & 11.4 & 17.6 & 0.07 & 1276 & 10.0 & 7.1 & 32.0 \\
\hline Control & 15.0 & 7.9 & 17.0 & 0.05 & 700.0 & 7.0 & 4.6 & 23.0 \\
\hline \multicolumn{9}{|c|}{2019} \\
\hline $\begin{array}{l}\text { Champ DP, } \\
\text { WDG }\end{array}$ & 14.0 & 5.1 & 19.2 & 0.10 & 1562 & 11.9 & 8.8 & 30.0 \\
\hline $\begin{array}{l}\text { Kocide } 2000, \\
\text { WDG, standard }\end{array}$ & 14.8 & 6.4 & 18.0 & 0.07 & 1970 & 12.2 & 15.8 & 22.0 \\
\hline Control & 12.8 & 5.2 & 17.0 & 0.07 & 1520 & 14.8 & 10.0 & 26.0 \\
\hline \multicolumn{9}{|c|}{2020} \\
\hline $\begin{array}{l}\text { Champ DP, } \\
\text { WDG }\end{array}$ & 12.9 & 11.0 & 13.2 & 0.11 & 1360 & 19.0 & 5.8 & 37.0 \\
\hline $\begin{array}{l}\text { Kocide } 2000 \text {, } \\
\text { WDG, standard }\end{array}$ & 12.1 & 9.8 & 13.4 & 0.05 & 1194 & 18.0 & 6.8 & 56.0 \\
\hline Control & 12.0 & 11.5 & 10.2 & 0.08 & 1290 & 20.0 & 6.6 & 54.0 \\
\hline $\mathrm{LSD}_{05}{ }^{*}$ & 0.88 & 1.30 & 1.30 & 0.11 & 13.86 & 1.58 & 1.37 & 2.74 \\
\hline
\end{tabular}

Note: LSD - Least Significant Difference 
Table 4. Biochemical composition of plum fruits during harvesting, 2018-2020.

\begin{tabular}{|c|c|c|c|c|c|c|c|c|}
\hline Variant & $\begin{array}{c}\text { Dry } \\
\text { matte } \\
\mathrm{r}, \%\end{array}$ & $\begin{array}{l}\text { Malic } \\
\text { acid, } \\
\mathrm{g} / \mathrm{kg}\end{array}$ & $\begin{array}{c}\text { Ascorbi } \\
\mathrm{c} \text { acid, } \\
\mathrm{mg} / \mathrm{kg}\end{array}$ & $\begin{array}{l}\text { Chloro } \\
\text { genic } \\
\text { acid, } \\
\mathrm{g} / \mathrm{kg}\end{array}$ & $\begin{array}{c}\mathrm{K}, \\
\mathrm{mg} / \mathrm{k} \\
\mathrm{g}\end{array}$ & $\begin{array}{c}\mathrm{Na}, \\
\mathrm{mg} / \mathrm{kg}\end{array}$ & $\begin{array}{c}\mathrm{Mg}, \\
\mathrm{mg} / \mathrm{k} \\
\mathrm{g}\end{array}$ & $\begin{array}{c}\mathrm{Ca}, \\
\mathrm{mg} / \mathrm{kg}\end{array}$ \\
\hline \multicolumn{9}{|c|}{2018} \\
\hline Cuproxat, SC & 16.7 & 9.3 & 22.1 & 13.1 & 2867 & 52.3 & 98.9 & 46.6 \\
\hline Terpen $\mathrm{C}, \mathrm{SC}$ & 14.4 & 8.0 & 18.1 & 20.5 & 3048 & 58.2 & 98.4 & 43.4 \\
\hline $\begin{array}{l}\text { Abiga-Peak, } \\
\text { BC, standard }\end{array}$ & 16.5 & 8.6 & 9.5 & 31.7 & 2776 & 54.1 & 94.3 & 44.1 \\
\hline Control & 14.4 & 10.2 & 11.7 & 10.8 & 2004 & 42.9 & 63.1 & 37.9 \\
\hline \multicolumn{9}{|c|}{2019} \\
\hline Cuproxat, SC & 18.7 & 12.5 & 1.6 & 3.0 & 1373 & 91.0 & 59.0 & 28.0 \\
\hline Terpen C, SC & 17.8 & 11.2 & 0.6 & 4.0 & 1257 & 113.0 & 64.0 & 42.0 \\
\hline $\begin{array}{l}\text { Abiga-Peak, } \\
\text { BC, standard }\end{array}$ & 15.8 & 8.8 & 0.8 & 3.9 & 1040 & 100 & 68.0 & 27.0 \\
\hline Control & 16.2 & 13.5 & 0.8 & 3.0 & 1172 & 149 & 54.0 & 43.0 \\
\hline \multicolumn{9}{|c|}{2020} \\
\hline Cuproxat, SC & 11.9 & 10.2 & 3.5 & 5.0 & 365 & 28.0 & 14.0 & 22.0 \\
\hline Terpen C, SC & 12.0 & 5.0 & 4.3 & 3.0 & 480 & 117.0 & 26.0 & 54.0 \\
\hline $\begin{array}{l}\text { Abiga-Peak, } \\
\text { BC, standard }\end{array}$ & 14.8 & 8.4 & 3.6 & 8.3 & 520 & 33.0 & 14.4 & 21.8 \\
\hline Control & 14.2 & 14.0 & 0.8 & 5.0 & 578 & 57.0 & 22.0 & 43.0 \\
\hline LSD $_{05}$ & 0.91 & 1.00 & 1.71 & 1.87 & 19.74 & 3.89 & 3.53 & 2.03 \\
\hline
\end{tabular}

\section{Conclusion}

Tests 2018-2020 showed a high efficiency of control of the pathogen of apple scab with modern fungicides based on copper hydroxide in extreme weather conditions. During the period of increased temperature conditions, the biological effectiveness of fungicides of the copper group against plum clotterosporia decreased. The use of fungicides of the chemical group of inorganic copper compounds in apple and plum protection systems did not have a negative effect on the biochemical composition of the fruits. With the predicted warming of the climate in combination with a prolonged dry period, one can expect an increase in the damaging effect of drugs of chemical genesis on apple and plum plants. Therefore, the use of the fungicide Champ DP, VDG on the apple tree, replacing the drug Abiga-Peak, VS with Cuproxat, KS and Terpen C, KS on the drain allows not only to reduce the pesticide load on the environment due to the lower rate of copper application, but also to reduce the damaging effect of factor on trees weakened by stress, as well as the risks of resistance of scab and clasterosporium pathogens to fungicides of other chemical groups and, thereby, biologize the protection technology.

\section{References}

1. G.V. Yakuba., I.G. Mishchenko. Fruit and viticulture of South of Russia, 63(3), 217-239 (2020) http://doi.org/10.30679/2219-5335-2020-3-63-217-239

2. G. Yuan, Ranking List of 2019 Top 20 Global Agrochemical Companies Recomposed, Graced by 11 Chinese Players, http://news.agropages.com/News/NewsDetail--$\underline{36626 . h t m l}$ 
3. J. Nekvinda, W.L. Santos, In: G. Anilkumar, S. Saranya (eds), Copper Catalysis in Orcanic Synthesis, 23-49 (Wiley-VCH Verlag GmbH \& Co. KGaA, 2020) https://doi.org/10.1002/9783527826445.ch3

4. O.V. Manylova, V.N. Chernyshkov, M.I. Kartashov, Vest. Altai. State Agr. Un., 5(163), 54-58 (2018) http://www.asau.ru/vestnik/2018/5/054-058.pdf

5. M. Jasinskia, M. Hughesa, H. W. Fraserb, S. Fitzgerald, J. J. Willwerth. Crop Protect., 139, 105377 (2021) https://doi.org/10.1016/j.cropro.2020.105377

6. R. Gergerich, R. Welliver, K. Osterbauer, S. Kamenidou, R. Martin, D. Golino, K. Eastwell, M. Fuchs, G. Vidalakis, E. Tzanetakis, Plant Dis., 99(2), 176-187 (2015) http://doi.org/10.1094/PDIS-07-14-0762-FE

7. Y. Yu, M. Xu, X. Ding, Z. Chu, H. Liu, Mol. Plant Pathol., 162, 496-505 (2021) https://doi.org/10.1111/mpp.12919

8. F. Celar, K. Kos, J Appl. Entomol., 144(5), 388-395 (2020) https://doi.org/10.1111/jen.12743

9. A. López-Prieto, A. Moldes, J. Cruz, B. Pérez Cid, J. Surfact. Deterg., 23(6), 1055-1066 (2020) https://doi.org/10.1002/jsde. 12463

10. V. Rossi, T. Caffi, S. E. Legler, G. Fedele. Crop Prot., 143, 105477 (2021) https://doi.org/10.1016/j.cropro.2020.105477

11. K. Weitbrecht, S. Schwab, Ch. Rupp, Evi Bieler, M. Dürrenberger, G. Bleyer, S. Schumacher, H.-H. Kassemeyer, R. Fuchs, E. Schlücker. Crop Prot., 139, 105382 (2021) https://doi.org/10.1016/j.cropro.2020.105382

12. S. Kuhne, D. Roßberg, P. Rőhrig, F. von Mering, F. Weihrauch, S. Kanthak, J. Kienzle, W. Patzwahl, E. Reiners. J. Gitzel, Org. Farm., 3(1), 66-75 (2017) http://doi.org/10.12924/of2017.03010066

13. V.V. Golubev, A.V. Kudryavtsev, A.S. Firsov, M.A. Safonov. Agricultural machines and technol., 4, 43-48 (2017) http://doi.org/10.22314/2073-7599-2017-4-43-48

14. Yu.V. Trunov, E.M. Tsukanova, E.N. Tkachev, O.A. Greznev, N.N. Sergeeva, N.I. $\begin{array}{lllll}\text { Nenko, Yu.F. Yakuba. Agricultural Biol., 1, 93-97 (2012) } & \end{array}$ http://doi.org/10.15389/agrobiology.2012.1.93eng

15. E.B. Goldin, V.G. Goldina. Ecosystems, Optimization and Protection, 4(23), 104-111 (2011). 